\title{
Hypertriglyceridaemic pancreatitis with eruptive xanthomas
}

\author{
Gorrepati Rohith 이, ${ }^{1}$ Bachavarahalli Sriramareddy Rajesh, ${ }^{1}$ Andi Rajendhran Keerthi, \\ Amaranathan Anandhi (1) ${ }^{2}$
}

'Department of Surgery, Jawaharlal Institute of Postgraduate Medical Education and Research, Puducherry, India ${ }^{2}$ Deaprtment of Surgery, Jawaharlal Institute of Post Graduate Medical Education and Research, Pondicherry, Pondicherry, India

\section{Correspondence to}

Dr Amaranathan Anandhi; anandhiramesh76@yahoo.in

Accepted 14 June 2021

\section{DESCRIPTION}

A 26-year-old man presented with severe upper abdominal pain radiating to the back for the past 2 days. He also had multiple episodes of non-bilious vomiting. He was a chronic smoker and an alcoholic for the past 8 years. He had no history of diabetes mellitus or any drug abuse. On examination, the patient was hyperventilating and in severe respiratory distress. There were multiple yellowish papular lesions over the extensor surface of bilateral forearms, arms (figure 1A) and dorsum of hands (figure 1B). He was febrile and blood pressure was $92 / 68 \mathrm{~mm} \mathrm{Hg}$ and pulse rate was $112 / \mathrm{min}$. When the blood was drawn for initial lab investigations, white cloudy opaque (lactescent) serum was observed (figure 1C). Total leucocyte count (15 X10^9/L), Serum amylase levels $(546 \mathrm{mg} / \mathrm{dL})$ and lipase levels $(346 \mathrm{mg} / \mathrm{dL})$ were elevated. Lipid profile of the patient showed elevated triglycerides (TG, 2928 $\mathrm{mg} / \mathrm{dL})$, total cholesterol $(601 \mathrm{mg} / \mathrm{dL})$, high-density lipo protein (HDL) cholesterol $(105 \mathrm{mg} / \mathrm{dL}) . \mathrm{He}$ was initially treated with aggressive intravenous fluid resuscitation and was haemodynamically stabilised. Intravenous analgesics were administered and he was kept on nil per oral and was started on intravenous fluid. A contrast-enhanced CT of the abdomen showed bulky pancreas with multiple intrapancreatic and peripancreatic collections with no evidence of necrosis, abscess or pseudocyst formation (figure 2), which confirmed the diagnosis of hypertriglyceridaemic pancreatitis (HTGP) with eruptive xanthomas. Patient was started on intravenous heparin and insulin for reducing the lipid level. He was started on orals the next day and was escalated to a normal diet and was discharged in a stable condition. Dietary modification was advised and he had no further episodes even after 1-year follow-up.
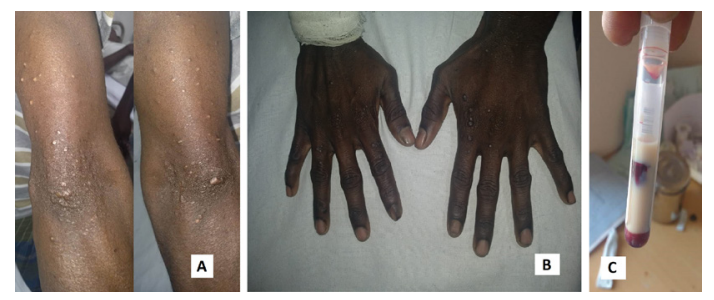

Figure 1 (A) Yellowish papular lesions over bilateral forearms; (B) Yellowish papular lesions over the dorsum of both the hands; (C) A plain sample collection tube containing lactescent serum.

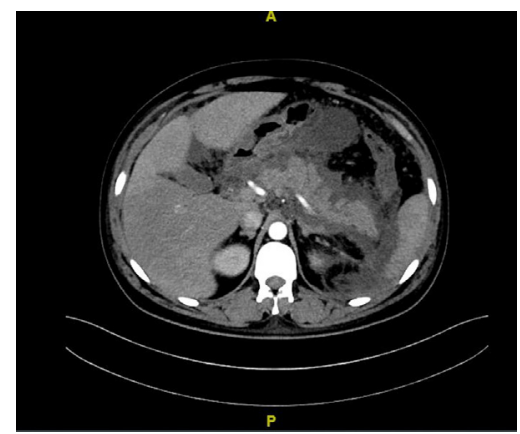

Figure 2 Transverse section of contrast-enhanced $\mathrm{CT}$ of abdomen showing bulky pancreas with multiple peripancreatic and intrapancreatic collections. (A Anterior, P -Posterior)

Severe hypertriglyceridaemia (HTG) (levels greater than $2000 \mathrm{mg} / \mathrm{dL}$ ) accounts for up to $10 \%$ of all the acute pancreatitis cases. ${ }^{1}$ High levels of TG are hydrolyzed by pancreatic lipases into glycerol and free fatty acids. These free fatty acids were thought to cause cytotoxic reaction, also damage to the vascular endothelium culminating in pancreatic inflammation and ischaemic injury. ${ }^{2}$ Although the clinical presentation is similar to pancreatitis caused by other causes, clinical signs

\section{Patient's perspective}

I had an episode of severe abdominal pain after I had an alcohol binge. It was a burning type of pain and I was unable to stand still due to its severity. I took an antacid but I felt nauseous and vomited thrice. I never had that severe pain ever before. We immediately went to a hospital where the doctors examined me and told me that my pancreas might have been the cause for my pain. They gave me some pain medication and inserted a tube into me through my nose. I was shocked and surprised when the doctor had told me that I had milky serum and might've been due to elevated lipids. They took a CT scan and told me that the problem was indeed with my pancreas. Doctors strictly asked me not to take anything by mouth and I complied. Pain was better the following day and I was started on water. I was instructed not to take alcohol, exercise regularly and to have a healthy lifestyle. I judiciously followed the doctor's instructions and it's been an year since the episode. I am quite healthy now. 
such as eruptive xanthomas that occur on the extensor surfaces of extremities should rise a clinical suspicion of HTGP. These lesions occur in $10 \%$ of the cases with HTG and usually point to a familial aetiology which is absent in our case. ${ }^{3}$ The serum levels of pancreatic enzymes can be falsely low when TG levels are $>500 \mathrm{mg} / \mathrm{mL}$ which is likely due to the interference of TG with the assay. ${ }^{4}$ The diagnosis of HTGP may be challenging as sometimes the TG levels may be normal due the nil oral intake by the patient because of sever pain abdomen, and in the absence of a clear aetiology patients should have a new test of TG levels after the acute attack has resolved and the patients has restored oral intake. ${ }^{5}$ Management is similar to acute pancreatitis due to other causes. The optimal treatment of HTG-associated pancreatitis is not clear at present. In many cases, the TG levels will likely normalise following nil per mouth and fluid therapy

\section{Learning points}

- Serum triglycerides (TG) level of $\geq 500 \mathrm{mg} / \mathrm{dL}$ in patients with acute pancreatitis (AP) should raise a high degree of suspicion of hypertriglyceridaemic pancreatitis (HTGP), especially when no other aetiology of AP seems apparent.

- Presentation of HTGP is similar to AP due to other aetiologies but due to high serum levels of circulating TG, the serum amylase levels may not be markedly elevated.

- Clinical course of patients with HTGP depends on the control of TG levels and so an early diagnosis, followed by quick initiation of lipid-lowering treatment is of paramount importance in the management of HTGP.

- Dietary and lifestyle modification, abstinence from alcohol along with lipid-lowering agents (statins+fibrates) are required in these patients for the control of TG levels and to prevent recurrences. without need of insulin/heparin or plasmapheresis. But if it is not normalised then additionally, intravenous heparin and insulin has to given as in the present case. Alternatively, plasmapheresis can be considered but its efficacy over medical management is not fully proven. ${ }^{1}$ TG levels of $<500 \mathrm{mg} / \mathrm{dL}$ are desirable to prevent recurrences which can be achieved by dietary modifications and antihyperlipidaemic drugs. ${ }^{4}$

\section{Twitter Bachavarahalli Sriramareddy Rajesh @rajeshbs89}

Contributors All authors have made substantive contributions to the study, and all authors endorse the data and conclusions. The authors have no commercial associations or sources of support that might pose a conflict of interest. The patient was under the care of AA. GR: data collection; writing-original draft, review and editing. ARK: data collection; writing original draft. BSR: supervision; writing-review and editing. AA: supervision; critical analysis, writing-review and editing

Funding The authors have not declared a specific grant for this research from any funding agency in the public, commercial or not-for-profit sectors.

Competing interests None declared.

Patient consent for publication Obtained.

Provenance and peer review Not commissioned; externally peer reviewed.

\section{ORCID iDs}

Gorrepati Rohith http://orcid.org/0000-0003-1081-027X

Amaranathan Anandhi http://orcid.org/0000-0001-8009-0445

\section{REFERENCES}

1 Valdivielso P, Ramírez-Bueno A, Ewald N. Current knowledge of hypertriglyceridemic pancreatitis. Eur J Intern Med 2014;25:689-94.

2 de Pretis N, Amodio A, Frulloni L. Hypertriglyceridemic pancreatitis: epidemiology, pathophysiology and clinical management. United European Gastroenterol J 2018:6:649-55.

3 Lee SY, Sheth CA. Eruptive xanthoma associated with severe hypertriglyceridemia and poorly controlled type 1 diabetes mellitus. J Community Hosp Intern Med Perspect 2019:9:344-6.

4 Scherer J, Singh VP, Pitchumoni CS, et al. Issues in hypertriglyceridemic pancreatitis: an update. J Clin Gastroenterol 2014;48:195-203.

5 Olesen SS, Harakow A, Krogh $\mathrm{K}$, et al. Hypertriglyceridemia is often under recognized as an aetiologic risk factor for acute pancreatitis: a population-based cohort study. Pancreatology 2021;21:334-41

Copyright 2021 BMJ Publishing Group. All rights reserved. For permission to reuse any of this content visit

https://www.bmj.com/company/products-services/rights-and-licensing/permissions/

BMJ Case Report Fellows may re-use this article for personal use and teaching without any further permission.

Become a Fellow of BMJ Case Reports today and you can:

- Submit as many cases as you like

Enjoy fast sympathetic peer review and rapid publication of accepted articles

- Access all the published articles

- Re-use any of the published material for personal use and teaching without further permission

Customer Service

If you have any further queries about your subscription, please contact our customer services team on +44 (0) 2071111105 or via email at support@bmj.com.

Visit casereports.bmj.com for more articles like this and to become a Fellow 